Published in final edited form as:

Psychopharmacology (Berl). 2001 February ; 154(1): 1-7.

\title{
Orphanin $\mathrm{FQ} /$ nociceptin attenuates motor stimulation and changes in nucleus accumbens extracellular dopamine induced by cocaine in rats
}

\author{
Kabirullah Lutfy, Toan Do, and Nigel T. Maidment \\ Department of Psychiatry and Biobehavioral Sciences, Neuropsychiatric Institute, University of \\ California, Los Angeles, 760 Westwood Plaza, Los Angeles, CA 90024, USA Tel.: +1-310-206 \\ -7890, Fax: +1-310-825-7067
}

\begin{abstract}
Rationale-Orphanin FQ (OFQ; also known as nociceptin), the endogenous ligand of the opioid receptor-like receptor, injected intracerebroventricularly (i.c.v.) decreases basal motor activity and basal extracellular levels of dopamine (DA) in the nucleus accumbens (Nuc Acc) in rats.
\end{abstract}

Objective-The present study was designed to determine if OFQ similarly attenuates cocaineinduced motor stimulation and to determine if this effect is dependent on attenuation of the increase in extracellular DA.

Methods-After a 1-h adaptation period, rats were injected with either artificial cerebrospinal fluid or OFQ (3-30 nmol, i.c.v.) $5 \mathrm{~min}$ prior to cocaine ( $10 \mathrm{mg} / \mathrm{kg}$, i.p.) or apomorphine (3 $\mathrm{mg} / \mathrm{kg}$, i.p.) administration and the total distance traveled was measured for a further $1 \mathrm{~h}$. In a separate experiment, changes in extracellular DA were monitored by microdialysis following cocaine and OFQ treatment in anesthetized rats.

Results-OFQ dose-dependently attenuated both basal and cocaine-induced motor stimulation. OFQ (30 nmol, i.c.v.) also attenuated both the basal and the cocaine-induced increase in extracellular DA in the Nuc Acc. OFQ, at the highest dose, also decreased the motor stimulation induced by apomorphine.

Conclusions-Our results suggest that the modulatory effect of OFQ on locomotor activity is not solely due to its inhibitory action on extracellular DA in the Nuc Acc.

\section{Keywords}

Orphanin FQ; Nociceptin; Opioid receptor-like (ORL-1) receptor; Cocaine; Apomorphine; Dopamine; Motor activity

\section{Introduction}

A large body of evidence suggests that an enhanced dopaminergic (DA-ergic) neurotransmission in certain forebrain areas is a critical factor in mediating the rewarding effects of psychostimulants, opiates, and other abused drugs. In particular, an increase in the activity of the mesoaccumbens axis, originating in the ventral tegmental area (VTA) and projecting to the nucleus accumbens (Nuc Acc), has been associated with drug reward (reviewed by Koob 1992). Conversely, a decrease in extracellular dopamine (DA) in the Nuc Acc is believed to mediate the aversive effects of certain drugs (reviewed by Herz 1998). Thus, 
modulation of DA-ergic neurotransmission along the mesoaccumbens axis could be a therapeutic intervention for management of drug dependency and addiction. However, there is still no convincing evidence that shows that DA-ergic drugs are successful as therapies for drug dependency (reviewed by Johanson and Fischman 1989).

Opioid drugs have been shown to modulate DA-ergic neurotransmission. Mu and delta opioid receptor agonists increase, whereas kappa opioid receptor agonists decrease extracellular DA in the Nuc Acc (Di Chiara and Imperato 1988; Spanagel et al. 1992). A new member of the opioid receptor family has been characterized (Bunzow et al. 1994; Chen et al. 1994; Fukuda et al. 1994; Mollereau et al. 1994). The term opioid receptor-like (ORL-1) receptor was coined for this new member of the guanine regulatory $(\mathrm{G})$ protein-coupled receptors because, despite structural similarities with classical opioid receptors, the ORL-1 receptor does not bind opiate drugs with appreciable affinity. The mRNA for the ORL-1 receptor is widely distributed in the central nervous system and in particular in areas involved in motivational and emotional behaviors (Mollereau et al. 1994; Peluso et al. 1998). Orphanin FQ (OFQ; also known as nociceptin), the heptadecapeptide endogenous ligand of the ORL-1 receptor, shows structural similarities to the endogenous opioid peptides and to dynorphin A (1-17) in particular. Similarly to dynorphin A (1-17) and other kappa opioid receptor agonists, OFQ has been shown to decrease extracellular DA in the Nuc Acc after intracerebroventricular (i.c.v.; Murphy et al. 1996) or intra-VTA injection (Murphy and Maidment 1999). Consistent with these neurochemical studies, behavioral experiments have shown that OFQ suppresses basal motor activity in rats (Devine et al. 1996b).

The ability of dynorphin A and other kappa opioid receptor agonists to decrease DA-ergic neurotransmission in the Nuc Acc (Di Chiara and Imperato 1988; Spanagel et al. 1992) led to the suggestion that these agents may be useful in cocaine addiction and psychosis. This is due to the fact that in both conditions hyperactivity of mesolimbic DA-ergic neurons is hypothesized (Matthysse 1973; Stevens 1973; Hokfelt et al. 1974; Post and Contel 1983; Robinson and Becker 1986; Robinson and Berridge 1993). However, the aversive properties of these agents would be predicted to hinder their therapeutic usefulness (reviewed by Herz 1998). OFQ, on the other hand, is apparently devoid of such side effects in rats (Devine et al. 1996a). Agonists at the ORL-1 receptor may therefore prove useful clinically.

Cocaine, by inhibiting the DA transporter at the synaptic terminals, elevates extracellular DA (Ritz et al. 1987; Reith 1988) which can be modeled as a hyperactive state of DA-ergic neurotransmission. We took advantage of this model to further examine the regulatory role of OFQ on the DA system. Therefore, the present investigation was designed to determine the ability of OFQ to attenuate the DA elevation and motor stimulation induced by acute cocaine administration. For comparison, the effect of $\mathrm{OFQ}$ was also examined on apomorphine-induced hyperactivity to determine if the effect of OFQ on motor behavior is solely mediated by a decrease in extracellular DA.

\section{Materials and methods}

\section{Subjects}

Male Sprague-Dawley rats (180-200 g) obtained from Harlan (Madison, Wis., USA) were kept under a 12-h light/dark cycle with food and water ad libitum. All experiments were conducted during the light cycle. A total of 209 rats were used for these experiments. Each of the five sets of experiments described were conducted in separate groups of rats. Moreover, each rat was used only once within each experiment. To determine the effect of various drugs on motor activity, each set consisted of 4 rats in which 1 rat of each group was included in every set. For measurement of extracellular DA, microdialysis was conducted in pairs of anesthetized rats in which 1 rat of each group was run side by side each day. 


\section{Surgical and microdialysis procedures}

For i.c.v. guide cannula implantation, rats were anesthetized with halothane in a mixture (1:1) of oxygen and nitrous oxide and placed in a stereotaxic frame. The skull was exposed and a $22 \mathrm{G}$ guide cannula $(\mathrm{ID}=0.39 \mathrm{~mm}$; $\mathrm{OD}=0.71 \mathrm{~mm}$; Plastic One, Roanoke, Va., USA) was implanted into the right lateral ventricle using the following coordinates according to the atlas of Paxinos and Watson (1986): $\mathrm{AP}=-0.8 \mathrm{~mm} ; \mathrm{ML}=+1.4 \mathrm{~mm}$; $\mathrm{DV}=-3.5 \mathrm{~mm}$. The guide cannula was secured to the skull by dental cement and two metallic screws. Rats were allowed at least 3 days to recover from the surgery. For microdialysis experiments, naive rats were anesthetized with halothane in a mixture of oxygen and nitrous oxide and a guide cannula was implanted in one of the lateral ventricles. On the contralateral side, a 2-mm microdialysis probe (concentric design, PAN AN69), continuously perfused with artificial cerebrospinal fluid (aCSF) at $2.0 \mu 1 / \mathrm{min}$, was lowered into the Nuc Acc. The coordinates, according to the atlas of Paxinos and Watson (1986), were $\mathrm{AP}=-0.8 ; \mathrm{ML}= \pm 1.4 \mathrm{~mm} ; \mathrm{DV}=-3.5 \mathrm{~mm}$ and $\mathrm{AP}=+1.6$ $\mathrm{mm} ; \mathrm{ML}= \pm 1.6 \mathrm{~mm} ; \mathrm{DV}=-7.5 \mathrm{~mm}$, respectively, for i.c.v. and Nuc Acc.

\section{Verification of probe placement and site of injection}

At the end of each experiment, rats were anesthetized with an overdose of pentobarbital (50 $\mathrm{mg} / \mathrm{kg}$, i.p.), injected with $2 \mu \mathrm{l}$ cresyl violet through the microdialysis probe or i.c.v. guide cannula and the brains were removed for sectioning and examination of probe/guide cannula placement. On the basis of such examination, eight rats in which either the microdialysis probe placement (three rats) or the guide cannula (five rats) was outside of the target region were removed from the data analysis.

\section{Experiment 1: effects of OFQ on motor stimulatory effects of cocaine}

Initially a dose-response for the motor stimulatory effect of cocaine alone in uncannulated naive rats was conducted in order to determine a submaximal non-stereotypic-inducing dose of cocaine for use in subsequent studies with OFQ. Rats were adapted to circular testing chambers $(34 \mathrm{~cm}$ diameter $\times 30 \mathrm{~cm}$ high made of gray plastic) for $1 \mathrm{~h}$. Rats were then temporarily removed from the testing chambers, randomly assigned, and injected with either saline ( $n=6$ rats) or cocaine $(3,10$, or $30 \mathrm{mg} / \mathrm{kg}$, i.p.; $n=8,10$, and 9 rats, respectively). The rats were immediately returned to the testing chambers and total horizontal distance $(\mathrm{cm})$ traveled was measured for $1 \mathrm{~h}$ using a Videomax-V motor activity apparatus (Columbus Instruments, Ohio, USA). In subsequent studies, a different set of rats was cannulated as described above and, 4 days later, tested for the effect of OFQ on cocaine-induced motor stimulation. Rats were adapted to the testing chambers for $1 \mathrm{~h}$. Rats were then injected with either aCSF (10 $\mu \mathrm{l} ; n=13$ rats) or $\mathrm{OFQ}(3,10$, or $30 \mathrm{nmol} / 10 \mu$ l, i.c.v.; $n=11,7$, and 15 rats, respectively) $5 \mathrm{~min}$ prior to cocaine $(10 \mathrm{mg} / \mathrm{kg}$, i.p.) administration and total horizontal distance $(\mathrm{cm})$ traveled was recorded for a further $1 \mathrm{~h}$.

\section{Experiment 2: effects of OFQ on cocaine-induced changes in Nuc Acc extracellular DA}

After a 2-h postimplantation stabilization period, dialysis samples were collected from the Nuc Acc at 15-min intervals while the rats were maintained under anesthesia. Three baseline samples were collected after which rats were injected i.c.v. with either aCSF (10 $\mu 1 ; n=6$ rats) or OFQ (30 nmol/10 $\mu \mathrm{l}, n=7$ rats) and 5 min later with cocaine ( $10 \mathrm{mg} / \mathrm{kg}$, i.p.). Seven more samples were collected. All samples were stored at $-70^{\circ} \mathrm{C}$ prior to assay for DA by highperformance liquid chromatography with electrochemical detection as described previously (Murphy and Maidment 1999).

\section{Experiment 3: effects of OFQ on motor stimulatory effects of apomorphine}

Similar to the cocaine experiments (see above), a dose-response study was first conducted for apomorphine alone (1,3, or $10 \mathrm{mg} / \mathrm{kg}$, i.p.; $n=10,6$, and 8 rats, respectively) in naive rats. 
Control rats received saline ( $n=8$ rats). In subsequent studies, a different set of rats was cannulated and, 4 days later, tested for the effect of OFQ on motor stimulation induced by a submaximal dose of apomorphine. Rats were adapted to the testing chambers for $1 \mathrm{~h}$. Rats were injected with either aCSF $(10 \mu \mathrm{l} ; n=11$ rats $)$ or $\mathrm{OFQ}(3,10$, or $30 \mathrm{nmol} / 10 \mu$ l, i.c.v., $n=6,6$, and 10 rats, respectively) $5 \mathrm{~min}$ prior to apomorphine ( $3 \mathrm{mg} / \mathrm{kg}$, i.p.) administration and the total distance traveled $(\mathrm{cm})$ was recorded for $1 \mathrm{~h}$.

\section{Experiment 4: effects of i.c.v. OFQ on basal motor activity}

Rats were cannulated and, 4 days later, adapted to the testing chambers for $1 \mathrm{~h}$. Rats were then injected i.c.v. with either aCSF $(10 \mu \mathrm{l} ; n=9$ rats $)$ or $\mathrm{OFQ}(3,10$, or $30 \mathrm{nmol} / 10 \mu \mathrm{l} ; n=8,7$, and 9 rats, respectively) and total distance $(\mathrm{cm})$ traveled was recorded for a further $1 \mathrm{~h}$.

\section{Experiment 5: effects of i.c.v. OFQ on basal extracellular DA in the Nuc Acc}

Naive rats were prepared for microdialysis and i.c.v. injection as described for experiment 2. After a 2-h postimplantation stabilization period, three baseline microdialysis samples (15 min each) were collected following which rats were injected i.c.v. with either aCSF (10 $\mu 1 ; n=5$ rats) or OFQ ( $30 \mathrm{nmol} / 10 \mu \mathrm{l}, n=6$ rats) and three further samples were then collected. Samples were frozen and stored at $-70^{\circ} \mathrm{C}$ prior to DA analysis as described (Murphy and Maidment 1999).

\section{Data analysis}

Motor activity data were analyzed using a one-way analysis of variance (ANOVA) followed by a Newman-Keuls post hoc test. Microdialysis data were normalized as percent of the final baseline sample prior to aCSF/OFQ treatment and the postinjection values were analyzed using repeated-measure ANOVAs in which the factors were treatment (aCSF or OFQ) and time after drug administration. $P<0.05$ was considered statistically significant.

\section{Drugs}

Cocaine (Sigma, St. Louis, Mo., USA) and apomorphine (Research Biochemicals International, Natick, Mass., USA) were dissolved in saline prior to i.p. administration. OFQ (Phoenix Pharmaceuticals, Mountain View, Calif., USA) was dissolved in aCSF for i.c.v. injection. The composition of aCSF in $\mathrm{mM}$ was: $\mathrm{NaCl}(125) ; \mathrm{KCl}(2.5) ; \mathrm{NaH}_{2} \mathrm{PO}_{4}(0.9)$; $\mathrm{Na}_{2} \mathrm{HPO}_{4}$ (5); $\mathrm{MgCl}_{2}$ (1); D-glucose (2.5); $\mathrm{CaCl}_{2}$ (1.2); bovine serum albumin (0.025\%). A $30 \mathrm{G}$ needle that extended $0.5 \mathrm{~mm}$ beyond the tip of the guide cannula was used for i.c.v. injection. OFQ or aCSF was injected in a volume of $10 \mu \mathrm{l}$ over $40 \mathrm{~s}$. The microinjection needle was removed after an additional $20 \mathrm{~s}$.

\section{Results}

\section{Experiment 1: effects of OFQ on motor stimulatory effects of cocaine}

Cocaine increased the total distance traveled during the 1-h recording period in a dosedependent fashion $[F(3,29)=11.64, P<0.05]$. The post hoc Newman-Keuls test revealed that cocaine increased motor activity at the two higher doses $(10$ and $30 \mathrm{mg} / \mathrm{kg}$ ) as compared to the saline-treated control group (Table $1 ; P<0.05$ ). In addition, the effect of cocaine at the highest dose was significantly greater than the two lower doses of the drug $(P<0.05)$. The effect of OFQ on motor stimulation induced by a submaximal dose of cocaine $(10 \mathrm{mg} / \mathrm{kg}$, i.p. $)$ is illustrated in Fig. 1. Analysis of the data by a one-way ANOVA revealed that OFQ attenuated the motor stimulatory effect of cocaine in a dose-dependent manner $[F(3,42)=7.61, P<0.05]$. Further analysis of the data using the post hoc Newman-Keuls test showed that OFQ, at 10 and $30 \mathrm{nmol}$, significantly decreased the motor stimulatory effect of cocaine $(P<0.05)$. In addition, 
the effect of OFQ was significantly different at the highest dose than the lowest dose of the drug $(P<0.05$; Fig. 1).

\section{Experiment 2: effects of OFQ on cocaine-induced changes in Nuc Acc extracellular DA}

The effect of OFQ at the highest dose tested in the behavioral study ( $30 \mathrm{nmol}$, i.c.v.) was also examined on the increase in Nuc Acc extracellular DA induced by cocaine $(10 \mathrm{mg} / \mathrm{kg})$ in anesthetized rats (Fig. 2). A repeated-measure ANOVA revealed a significant effect of time $[F(6,66)=9.77, P<0.05]$, indicating that extracellular DA was increased by cocaine across control and OFQ-treated groups. Furthermore, there was a significant effect of treatment $[F$ $(1,11)=4.71, P<0.05]$, indicating that the effect of cocaine was significantly attenuated in the OFQ-treated group. There was, however, no significant interaction between time and treatment $[F(6,66)=2.24, P>0.05]$, indicating that the cocaine-induced increase in extracellular DA, even though smaller in the OFQ-treated rats, showed a similar time-course in both groups.

\section{Experiment 3: effects of OFQ on motor stimulatory effects of apomorphine}

As expected, apomorphine alone also increased motor activity in a dose-dependent fashion $[F(3,28)=12.08, P<0.05 ;$ Table 1]. Further analysis of the data by the post hoc Newman-Keuls test revealed that apomorphine at the two higher doses $(3$ and $10 \mathrm{mg} / \mathrm{kg}$ ) produced a significant increase in motor activity as compared to the saline-treated control group $(P<0.05)$.

Furthermore, the effect of the highest dose of apomorphine $(10 \mathrm{mg} / \mathrm{kg})$ was significantly greater than the two lower doses of the drug $(P<0.05$; Table 1$)$. The effect of OFQ was also studied on motor stimulation induced by a submaximal dose of apomorphine ( $3 \mathrm{mg} / \mathrm{kg}$, i.p.; Fig. 1). OFQ significantly reduced the motor stimulatory effect of apomorphine in a dose-dependent manner $[F(3,29)=3.62, P<0.05]$. Further analysis of the data using the post hoc Newman-Keuls test showed that OFQ attenuated the motor stimulatory effect of apomorphine only at the highest dose $(P<0.05)$.

\section{Experiment 4: effects of i.c.v. OFQ on basal motor activity}

OFQ significantly decreased total distance traveled at all three doses $[F(3,29)=4.27, P<0.05$; Table 1].

\section{Experiment 5: effects of i.c.v. OFQ on basal extracellular DA in the Nuc Acc}

OFQ $(30 \mathrm{nmol})$ reduced extracellular DA in the Nuc Acc in anesthetized rats by approximately $30 \%$ as compared to the aCSF-treated control group (Fig. 3). A repeated-measure ANOVA showed a significant effect of treatment $[F(1,9)=10.59, P<0.05]$, time $[F(2,18)=14.12$, $P<0.05]$, and treatment $\times$ time interaction $[F(2,18)=13.34, P<0.05]$, indicating that a differential time-dependent change in extracellular DA was observed which was significantly attenuated by treatment with OFQ as compared to aCSF $(P<0.05)$.

\section{Discussion}

The main finding of the present investigation is that $\mathrm{OFQ}$ attenuated both the motor stimulatory and extracellular DA elevating effect of cocaine, an inhibitor of the DA transporter. Furthermore, OFQ decreased the motor stimulatory effect of apomorphine, a direct DA receptor agonist, the effect of which is independent of changes in extracellular DA levels.

Opioid drugs have been shown to modulate DA-ergic neurotransmission. For example, mu and delta opioid receptor agonists increase extracellular DA in the Nuc Acc. However, agonists of the kappa opioid receptor decrease extracellular DA (Di Chiara and Imperato 1988; Spanagel et al. 1992). OFQ, characterized as the endogenous agonist of the ORL-1 receptor, shows structural similarities to opioid peptides and in particular to dynorphin A (1-17) (Meunier et 
al. 1995; Reinscheid et al. 1995). Interestingly, OFQ administration has also been shown to suppress basal motor activity (Devine et al. 1996b) and reduces basal extracellular DA in the Nuc Acc of anesthetized rats (Murphy et al. 1996) after i.c.v. administration. These findings were reproduced in the present study.

In order to further our understanding of the mechanism of action of OFQ on the DA system, the effect of OFQ was evaluated on cocaine-induced motor stimulation and cocaine-induced increases in extracellular DA. I.c.v. administration of OFQ profoundly attenuated the motor stimulatory effect of cocaine in a dose-dependent manner. The amplitude of this reduction could not be accounted for simply by the effect on basal motor activity which was considerably smaller. Moreover, the dose-response relationship was different for the two effects with OFQ at the lowest dose maximally blocking basal motor activity but having no significant effect on the motor stimulatory effect of cocaine. It should also be noted that hind limb flaccidity frequently observed at higher doses (Devine et al. 1996b) was not apparent at the doses used in this study.

I.c.v. application of OFQ also attenuated the cocaine-induced increase in extracellular DA in the Nuc Acc in anesthetized rats, indicating that OFQ may produce its action on motor behavior by a DA-dependent mechanism on the mesoaccumbens axis. Consistent with this notion, we have found that administration of OFQ in the VTA attenuates basal motor activity (Lutfy et al. 2000). Furthermore, our laboratory has previously shown that OFQ administered in the VTA suppresses extracellular DA in the Nuc Acc in anesthetized rats (Murphy and Maidment 1999). However, the observation that OFQ also attenuated the motor stimulatory effect of the direct DA $D_{1} / D_{2}$ receptor agonist, apomorphine, suggests that OFQ may exert its motor behavioral action independent of reduction in extracellular DA. Since there is no evidence of a direct interaction of OFQ with DA receptors and given OFQ's action as an inhibitory modulator of neurotransmission (Murphy et al. 1996; Nicol et al. 1997), the most likely explanation is that OFQ is inhibiting neurons normally activated, either directly or indirectly, by DA receptor stimulation. The lack of motor effects following OFQ injection into the Nuc Acc (Stratford et al. 1997) suggests the need to consider other motor brain regions beyond the Nuc Acc in the search for OFQ's site of action in this regard. For example, OFQ has been shown to decrease glutamate release in cortical slices (Nicol et al. 1997).

In summary, our results suggest that the action of OFQ on motor behavior may not be solely mediated by decreases in extracellular DA in the Nuc Acc but rather may involve a combination of actions on the mesoaccumbens axis and at other motor regulatory regions distal to postsynaptic DA receptors.

\section{Acknowledgements}

We would like to express our sincere gratitude to Dr. Shridhar Narayanan for his comments. We also thank Imran Khaliq and Long Doan for technical assistance. This study was supported in part by a NIDA grant K01 DA00411 and a NARSAD Young Investigator Award to K.L and NIDA grant DA05010 and DA09359 to N.T.M.

\section{References}

Bunzow JR, Saez C, Mortrud M, Bouvier C, Williams JT, Low M, Grandy DK. Molecular cloning and tissue distribution of a putative member of the rat opioid receptor gene family that is not a mu, delta or kappa opioid receptor type. FEBS Lett 1994;347:284-288. [PubMed: 8034019]

Chen Y, Fan Y, Liu J, Mestek A, Tian M, Kozak CA, Yu L. Molecular cloning, tissue distribution and chromosomal localization of a novel member of the opioid receptor gene family. FEBS Lett 1994;347:279-283. [PubMed: 8034018]

Devine DP, Reinscheid RK, Monsma FJ Jr, Civelli O, Akil H. The novel neuropeptide orphanin FQ fails to produce conditioned place preference or aversion. Brain Res 1996a;727:225-229. [PubMed: 8842403] 
Devine DP, Taylor L, Reinscheid RK, Monsma FJ Jr, Civelli O, Akil H. Rats rapidly develop tolerance to the locomotor-inhibiting effects of the novel neuropeptide orphanin FQ. Neurochem Res 1996b; 21:1387-1396. [PubMed: 8947929]

Di Chiara G, Imperato A. Opposite effects of mu and kappa opiate agonists on dopamine release in the nucleus accumbens and in the dorsal caudate of freely moving rats. J Pharmacol Exp Ther 1988;244:1067-1080. [PubMed: 2855239]

Fukuda K, Kato S, Mori K, Nishi M, Takeshima H, Iwabe N, Miyata T, Houtani T, Sugimoto T. cDNA cloning and regional distribution of a novel member of the opioid receptor family. FEBS Lett 1994;343:42-46. [PubMed: 8163014]

Herz A. Opioid reward mechanisms: a key role in drug abuse? Can J Physiol Pharmacol 1998;76:252258. [PubMed: 9673788]

Hokfelt T, Ljungdahl A, Fuxe K, Johansson O. Dopamine nerve terminals in the rat limbic cortex: aspects of the dopamine hypothesis of schizophrenia. Science 1974;184:177-179. [PubMed: 4856104]

Johanson CE, Fischman MW. The pharmacology of cocaine related to its abuse. Pharmacol Rev 1989;41:3-52. [PubMed: 2682679]

Koob GF. Neurobiological mechanisms in cocaine and opiate dependence. Res Publ Assoc Res Nerv Ment Dis 1992;70:79-92. [PubMed: 1311123]

Lutfy, K.; Narayanan, S.; Maidment, NT. Orphanin FQ/nociceptin suppresses motor activity via a selective action on the mesoaccumbens axis. Third Eur Opioid Conference T12; Guildford, UK: 2000.

Matthysse S. Antipsychotic drug actions: a clue to the neuropathology of schizophrenia? Fed Proc 1973;32:200-205. [PubMed: 4348519]

Meunier JC, Mollereau C, Toll L, Suaudeau C, Moisand C, Alvinerie P, Butour JL, Guillemot JC, Ferrara $\mathrm{P}$, Monsarrat B, et al. Isolation and structure of the endogenous agonist of opioid receptor-like ORL1 receptor (see comments). Nature 1995;377:532-535. [PubMed: 7566152]

Mollereau C, Parmentier M, Mailleux P, Butour JL, Moisand C, Chalon P, Caput D, Vassart G, Meunier JC. ORL1, a novel member of the opioid receptor family. Cloning, functional expression and localization. FEBS Lett 1994;341:33-38. [PubMed: 8137918]

Murphy NP, Maidment NT. Orphanin FQ/nociceptin modulation of mesolimbic dopamine transmission determined by microdialysis. J Neurochem 1999;73:179-186. [PubMed: 10386969]

Murphy NP, Ly HT, Maidment NT. Intracerebroventricular orphanin FQ/nociceptin suppresses dopamine release in the nucleus accumbens of anaesthetized rats. Neuroscience 1996;75:1-4. [PubMed: 8923516]

Nicol B, Lambert DG, Rowbotham DJ, Smart D, McKnight AT. Nociceptin induced inhibition of $\mathrm{K}^{+}$ evoked glutamate release from rat cerebrocortical slices. Br J Pharmacol 1997;119:1081-1083. [PubMed: 8937708]

Paxinos, G.; Watson, C. The rat brain in stereotaxic coordinates. 2nd edn.. Academic Press; San Diego: 1986.

Peluso J, LaForge KS, Matthes HW, Kreek MJ, Kieffer BL, Gaveriaux-Ruff C. Distribution of nociceptin/ orphanin FQ receptor transcript in human central nervous system and immune cells. J Neuroimmunol 1998;81:184-192. [PubMed: 9521621]

Post, RM.; Contel, NR. Human and animal studies of cocaine: implications for development of behavioral pathology.. In: Creese, I., editor. Stimulants: neurochemical. behavioral and clinical perspectives Raven Press; New York: 1983. p. 169-203.

Reinscheid RK, Nothacker HP, Bourson A, Ardati A, Henningsen RA, Bunzow JR, Grandy DK, Langen $\mathrm{H}$, Monsma FJ Jr, Civelli O. Orphanin FQ: a neuropeptide that activates an opioidlike G proteincoupled receptor. Science 1995;270:792-794. [PubMed: 7481766]

Reith ME. Cocaine receptors on monoamine transporters and sodium channels. NIDA Res Monogr 1988;88:23-43. [PubMed: 2850501]

Ritz MC, Lamb RJ, Goldberg SR, Kuhar MJ. Cocaine receptors on dopamine transporters are related to self-administration of cocaine. Science 1987;237:1219-1223. [PubMed: 2820058]

Robinson TE, Becker JB. Enduring changes in brain and behavior produced by chronic amphetamine administration: a review and evaluation of animal models of amphetamine psychosis. Brain Res 1986;396:157-198. [PubMed: 3527341] 
Robinson TE, Berridge KC. The neural basis of drug craving: an incentive-sensitization theory of addiction. Brain Res Rev 1993;18:247-291. [PubMed: 8401595]

Spanagel R, Herz A, Shippenberg TS. Opposing tonically active endogenous opioid systems modulate the mesolimbic dopaminergic pathway. Proc Natl Acad Sci USA 1992;89:2046-2050. [PubMed: 1347943]

Stevens JR. An anatomy of schizophrenia? Arch Gen Psychiatry 1973;29:177-189. [PubMed: 4147475]

Stratford TR, Holahan MR, Kelley AE. Injections of nociceptin into nucleus accumbens shell or ventromedial hypothalamic nucleus increase food intake. Neuroreport 1997;8:423-426. [PubMed: 9080421] 


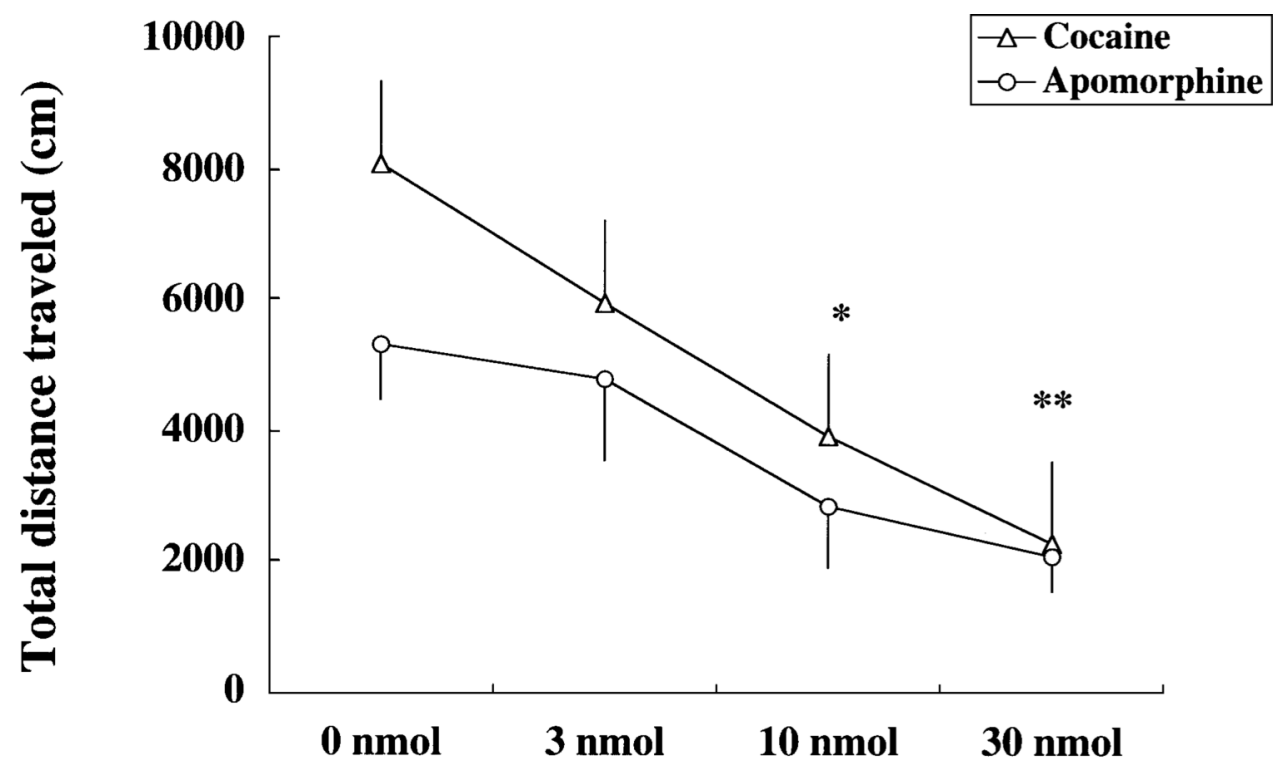

\section{OFQ (i.c.v.)}

Fig. 1.

Orphanin FQ (OFQ) dose-dependently [3, 10, or $30 \mathrm{nmol}$, intracerebroventricularly (i.c.v.)] attenuated the motor stimulatory effect of cocaine $(10 \mathrm{mg} / \mathrm{kg})$ or apomorphine $(3 \mathrm{mg} / \mathrm{kg})$. Data are means \pm SEM. *Significantly different from the respective control group (cocaine experiment) $(P<0.05$; revealed by the post hoc Newman-Keuls test). $* *$ Significantly different from the respective control group (apomorphine and cocaine experiment) and OFQ ( $3 \mathrm{nmol}$ )treated group (cocaine experiment) $(P<0.05$; revealed by the post hoc Newman-Keuls test) 


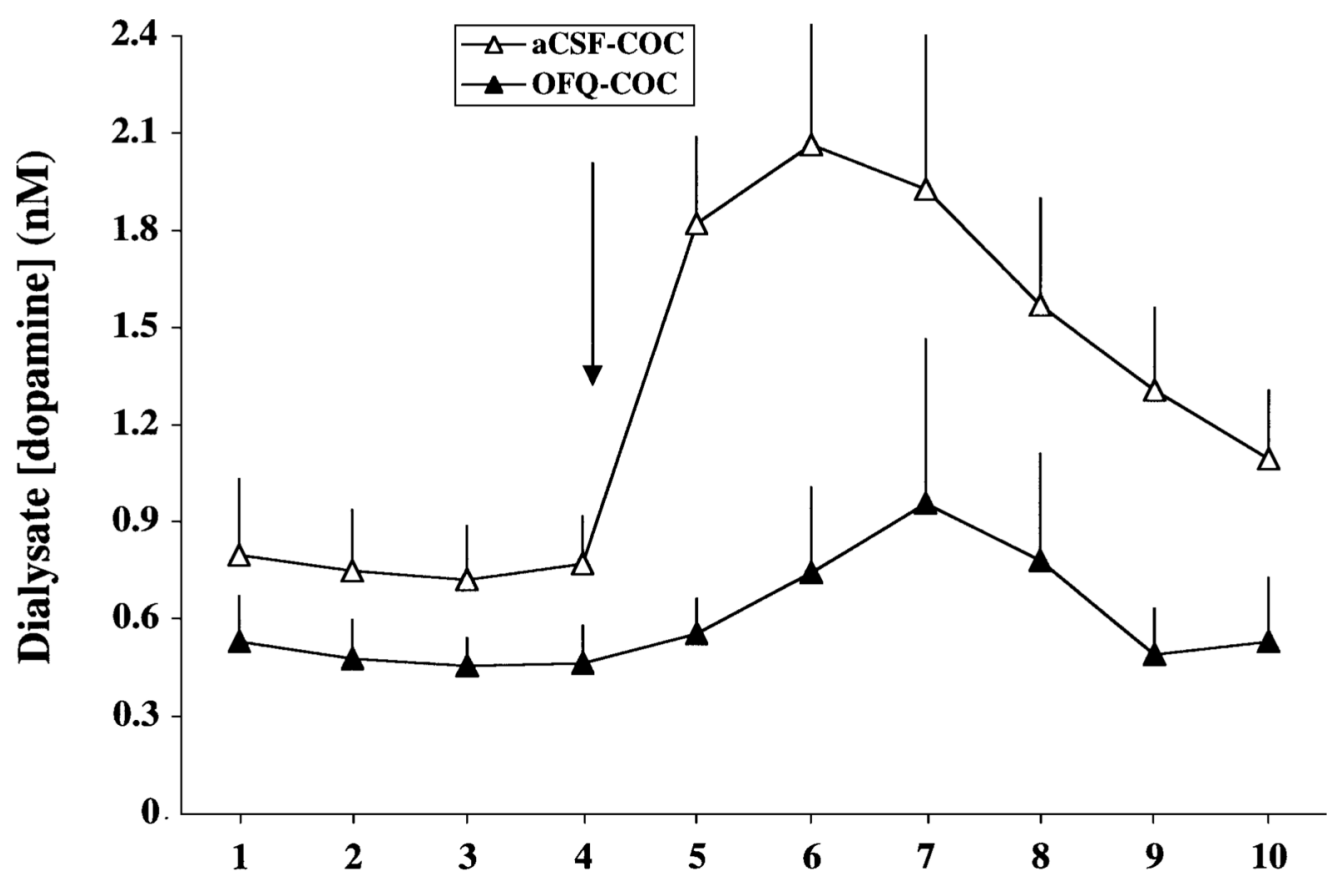

Sample number

Fig. 2.

OFQ (30 nmol, i.c.v.) attenuated the increase in nucleus accumbens (Nuc Acc) extracellular dopamine (DA) induced by cocaine $(10 \mathrm{mg} / \mathrm{kg}$, i.p.) in anesthetized rats. The arrow indicates the time of artificial cerebrospinal fluid (aCSF) or OFQ injection followed ( 5 min later) by cocaine administration. The first three time intervals are basal levels of DA and the sampling time was $15 \mathrm{~min}$. Data are means \pm SEM 


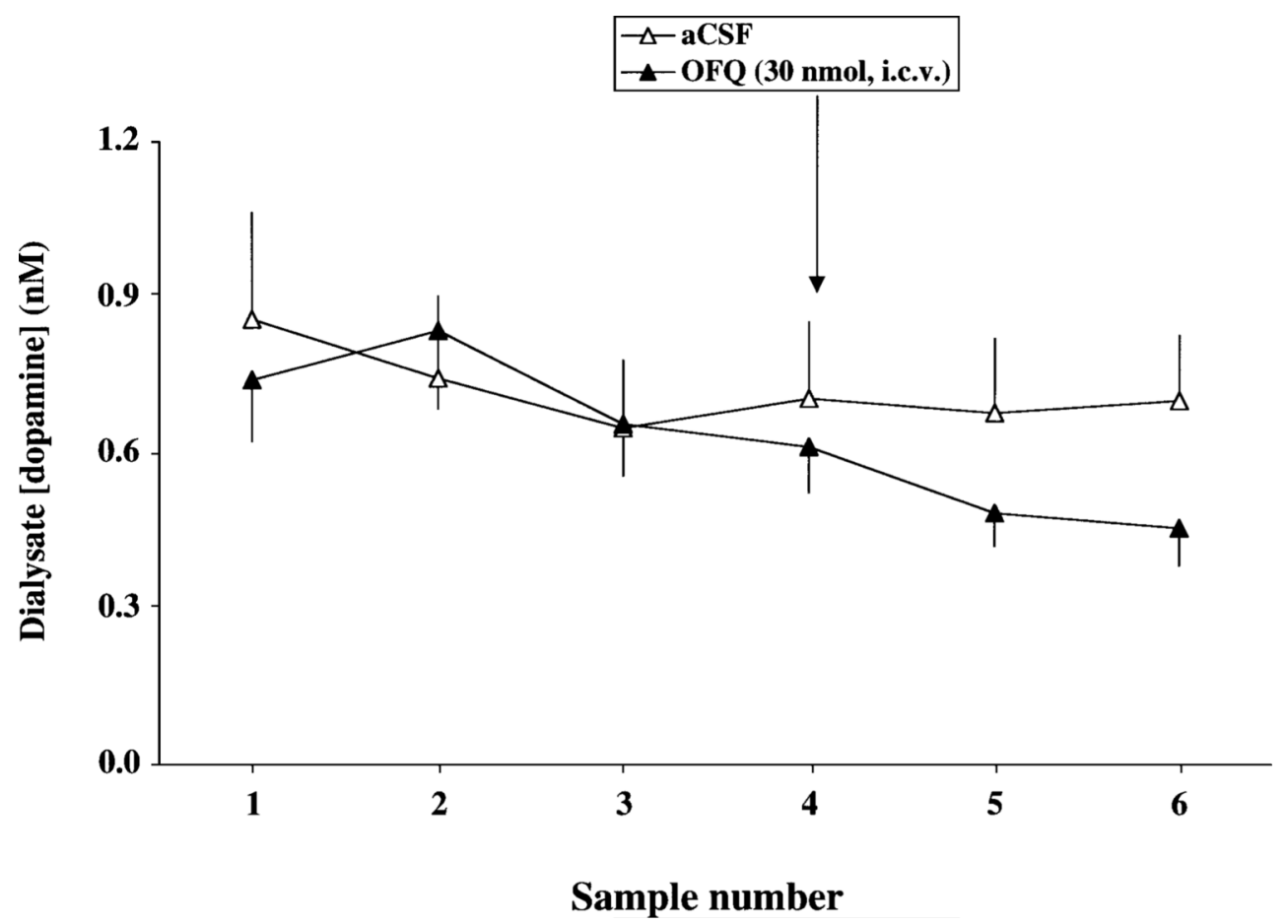

Fig. 3.

OFQ attenuated basal extracellular DA in the Nuc Acc in anesthetized rats. The arrow indicates the time of aCSF or OFQ administration. The first three time intervals are basal levels of DA and the sampling time was $15 \mathrm{~min}$. Data are means \pm SEM 
Table 1

Cocaine and apomorphine increased, whereas orphanin FQ $(O F Q)$ suppressed basal motor activity in rats. Rats were adapted to the testing chambers for $1 \mathrm{~h}$ and were then injected with a drug or vehicle and total distance traveled $(\mathrm{cm})$ was measured for a further 1 h. $a C S F$ Artificial cerebrospinal fluid

Treatment

Total distance traveled $(\mathrm{cm})$ in $1 \mathrm{~h}$

Number of rats

Saline (i.p.)

Cocaine $(3 \mathrm{mg} / \mathrm{kg}$, i.p.)

Cocaine $(10 \mathrm{mg} / \mathrm{kg}$, i.p. $)$

Cocaine $(30 \mathrm{mg} / \mathrm{kg}$, i.p.)

Saline (i.p.)

Apomorphine ( $1 \mathrm{mg} / \mathrm{kg}$, i.p.)

Apomorphine ( $3 \mathrm{mg} / \mathrm{kg}$, i.p.)

Apomorphine $(10 \mathrm{mg} / \mathrm{kg}$, i.p.)

aCSF (i.c.v.)

OFQ (3 nmol, i.c.v.)

OFQ (10 nmol, i.c.v.)

OFQ (30 nmol, i.c.v.)

* Significantly different from the respective saline/aCSF control group $(P<0.05$; revealed by the post hoc Newman-Keuls test $)$

**

Significantly different from all other groups $(P<0.05$; revealed by the post hoc Newman-Keuls test) 